\title{
Management of Soil Mulch in Weed Suppression and Sugarcane Productivity
}

\author{
Danilo C. O. de Cerqueira ${ }^{1}$, Vilma M. Ferreira ${ }^{2}$, Renan C. de Souza ${ }^{2}$, João C. de Araújo Neto ${ }^{2}$, \\ Vinicius S. G. da Silva ${ }^{2} \&$ Freds F. A. de Almeida ${ }^{2}$ \\ ${ }^{1}$ Federal Institute of Alagoas, Murici, Alagoas, Brazil \\ ${ }^{2}$ Center of Agricultural Sciences, Federal University of Alagoas, Rio Largo, Brazil \\ Correspondence: Vinicius S. G. da Silva, Center of Agricultural Sciences, Federal University of Alagoas, Rio \\ Largo, Brazil. Tel: 55-82-3261-1351. E-mail: vinicius.agro2008.1@gmail.com
}

Received: April 23, 2018

doi:10.5539/jas.v10n8p125

\author{
Accepted: June 6, 2018 Online Published: July 15, 2018 \\ URL: https://doi.org/10.5539/jas.v10n8p125
}

The research is financed by Coordination for Improvement of Higher Education Personnel (CAPES).

\begin{abstract}
The soil mulch is an agricultural practice that can benefit soil fertility and can be effective in suppressing weeds. The objective this research was to evaluate the mulching from legumes in weed control and sugarcane (first harvest/cut) productivity, comparing the results with the conventional application of herbicides. This research was carried out under field conditions. Five legumes were managed in two ways to form the soil cover: (1) mechanical topple, and (2) chemically desiccated. To compare the results, used treatments with herbicides applied in pre and pre + post emergence. The soil mulch from mechanical topple of Crotalaria spectabilis, $C$. juncea, C. ochroleuca, C. breviflora and Cajanus cajan presented lower efficiency in suppressing weeds than the treatment with herbicides applied in pre + post-emergence, however, were more efficient in controlling weeds in relation to the use of herbicides in pre-emergence, a fact observed at 60 days of sugarcane cultivation.
\end{abstract}

Keywords: Crotalaria spp., Cajanus cajan, Sugarcane (first harvest/cut), soil mulch

\section{Introduction}

In Brazil, the sugarcane as one of the crops which more agrochemicals are used, especially herbicide. Among the main damages caused by agrochemicals, we can mention destruction of soil microbiota balance (Mueller \& Senseman, 2015), contamination of the water table, surface or underground; air contamination; death of insects and natural enemies and numerous diseases, including kidney diseases and cancers, are correlated with increased herbicide use in crops (Samsel \& Seneff, 2013).

One alternative to control weed's in sugarcane that can reduce the use of herbicides is the formation of mulching over the soil. Plants of the Leguminosae family with high productivity of biomass can be cultivated and managed to form the cover. This practice interferes in infestation and establishment of weeds by physical, chemical and biological means (Teixeira et al., 2014). In the State of Alagoas, Northeastern Region of Brazil, the most used legumes in the renewal area of sugarcane, are of the genus Crotalaria and the species Cajanus cajan (popular name: bean-guandu-dwarf) (Silva et al., 2016). Among the benefits provided by this practice are increment in macro and micronutrients (Oliveira et al., 2017); increase in organic matter (Garcia-Franco et al., 2015); increase in nitrogen availability (Santos et al., 2017) and nutrient recycle (Sharifi et al., 2014). In addition to these benefits to soil fertility, the soil mulch from legumes can suppress weeds (Gomes et al., 2014; Mhlanga et al., 2015).

When legumes topple on the soil surface, without incorporation, they negatively interfere in the germination of positive photoblastic seeds, those that require light for germination (Yamauti et al., 2011). Tridax procumbens seeds, for example, are photoblastic positive; don't germinate without the presence of light and therefore the infestation of this weed is intensely reduced in the crops with soil cover (Guimarães et al., 2002).

Another effect of soil cover is the physical barrier that hinders the survival of seedlings of weeds with small quantities of reserves in the diaspores (seed dispersal structures). Often the reserves are not sufficient to ensure 
the survival of the seedlings in the process of their emergence through the mulching of the soil, since the germination until it has access to the light to initiate the photosynthesis, then these weeds suppress (Monquero et al., 2009).

In view of all the aforementioned aspects and the possibility of using mulch as a component inside the integrated weed management, serving as an alternative method in detriment to the use of herbicides, the objective of this research was to evaluate the efficiency of the soil mulch as of five legumes in weed control and sugarcane (first harvest/cut) productivity, comparing the results with herbicide efficiency.

\section{Materials and Methods}

This research was conducted under field conditions at Farm Santa Luzia, lot 31, Cansanção de Sinimbu Sugarcane Industry, Jequiá da Praia, AL (Figure 1). During the experiment, the accumulated rainfall was 1416 $\mathrm{mm}$ and the average temperature was $25.7^{\circ} \mathrm{C}$. The soil of the experimental area is a Distrocoesal Yellow Argisol (Embrapa, 2013). It's an area of renewal of sugarcane plantation, which for more than 20 years has been cultivated with sugarcane.

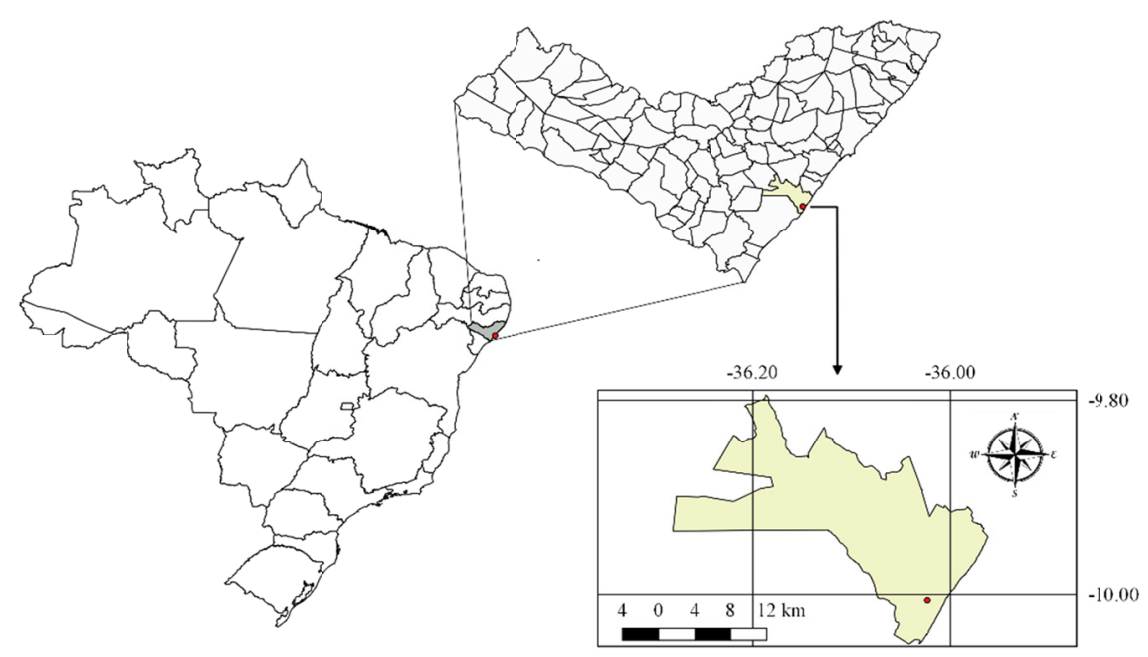

Figure 1. Location of the experimental area

The experiment was a $2 \times 6+2$ factorial design. The two factors were the soil mulch and the management of this mulch, besides two additional treatments. Were six kind of mulches: C. spectabilis, C. juncea, C. ochroleuca, $C$. breviflora, Cajanus cajan and without soil mulch from legumes. On the other hand, the two treatments were without herbicides and with herbicides.

For evaluate the suppression of weeds, five legumes seeded on September 1, 2011 and cultivated until December 20,2011 , period that the biomass was determined for the formation of mulch. The other plots remained covered with spontaneous vegetation. The management of this soil mulch done in two ways: (1) topple over the ground with the support of a tractor that tractioned a metal bar breaking the stem of the plants, or (2) the same species desiccated with herbicides. Therefore, the soil mulch formed by two managements: mechanical topple (mechanical management) or desiccation with herbicides (chemical management).

The chemical management of legumes performed as follows: for chemical desiccation, herbicides with post-emergence and pre-emergence used in the mix ( $200 \mathrm{~g}$ paraquat $+960 \mathrm{~g}$ metribuzin $+1066 \mathrm{~g}$ diurom $+134 \mathrm{~g}$ hexazinone per hectare). For the additional treatment 1 only a post-emergence herbicide $(200 \mathrm{~g}$ of paraquat per hectare) used to desiccate $C$. spectabilis. For the additional treatment 2, pre-emergence herbicides applied directly on the soil without mulch after planting the sugarcane $(960 \mathrm{~g}$ of metribuzin $+1066 \mathrm{~g}$ of diurom $+134 \mathrm{~g}$ of hexazinone per hectare) (Table 1). After 10 days of application of the herbicides, the planting grooves opened in the experimental area and the sugarcane planting, variety RB 92579, spaced in 1.0 m between lines. 
Table 1. List of treatments and respective descriptions

\begin{tabular}{|c|c|c|}
\hline \multirow{2}{*}{ Treatments $\left(\mathrm{N}^{\mathrm{o}}\right)$-Soil Mulch (SM) and Management (M) } & \multicolumn{2}{|r|}{ Description } \\
\hline & Dry mass $\left(\mathrm{t} \mathrm{ha}^{-1}\right)$ & Herbicide (dose) $\left(\mathrm{g} \mathrm{ha}^{-1}\right)$ \\
\hline \multicolumn{3}{|l|}{ Mechanical Management_-Mechanical Topple } \\
\hline C. spectabilis (1) & 6.0 & - \\
\hline C. juncea (3) & 6.5 & - \\
\hline C. ochroleuca (5) & 6.5 & - \\
\hline C. breviflora (7) & 1.0 & - \\
\hline Cajanus cajan (9) & 6.5 & - \\
\hline Without Soil Mulch (11) & - & - \\
\hline \multicolumn{3}{|c|}{ Chemical Management - Desiccation with Herbicide (Mix PRE and POST) } \\
\hline C. spectabilis (2) & 6.0 & \\
\hline C. juncea (4) & 6.5 & \\
\hline C. ochroleuca (6) & 6.5 & Paraquat (200) + Metribuzin (960) + Diurom (1066) \\
\hline C. breviflora $(8)$ & 1.0 & + Hexazinone (134) \\
\hline Cajanus cajan (10) & 6.5 & \\
\hline Without Soil Mulch (12) & - & \\
\hline \multicolumn{3}{|l|}{ Two additional Treatments } \\
\hline $1=C$. spectabilis + post-emergence $(13)$ & 6.5 & Paraquat (200) \\
\hline $2=$ Without Soil Mulch + pre-emergence $(14)$ & - & Metribuzin (960) + Diurom (1066) + Hexazinone (134) \\
\hline
\end{tabular}

During two seasons: at 30 and 60 days after planting (DAP), evaluated the effects of mulching on weed suppression between the lines of sugarcane plantation. Evaluated also two variables in the weeds: phytomass and plant density, using a methodology adapted from the square inventory (Braun-Blanquet, 1950), which based on the use of a square of $1.0 \times 1.0 \mathrm{~m}$, randomly placed inside the crops, however in this experiment a rectangle 0.5 $\times 1.0 \mathrm{~m}$ used, randomly placed in each experimental plot. At 12 months of cultivation, the sugarcane harvested and the data of agricultural productivity (TCH) and industrial yield (TPH) obtained.

The statistical design used was a randomized block design with four blocks and experimental plots of $6 \mathrm{~m} \times 8 \mathrm{~m}$. The collected data submitted to analysis of variance and the means tested by the Scott-Knott grouping test up to 5\% probability. The calculations performed using Assistat version 7.7 beta (Silva and Azevedo, 2016).

Contrasts (C) also performed between some treatments, obtained by the $t$ test in the Scheffé method: $\mathrm{C} 1$ (1 vs 13) corresponding to the contrast between $C$. spectabilis with mechanical topple and $C$. spectabilis desiccated with post-emergence herbicides; $\mathrm{C} 2(1+3+5+7+9$ vs 11) corresponding to the contrast between the five legumes submitted to the mechanical topple and the treatment without cover and without herbicides; $\mathrm{C} 3(2+4+6+8+$ 10 vs 12) corresponding to the contrast between chemically desiccated legumes and treatment with just herbicides and without soil cover; $\mathrm{C} 4(1+3+5+7+9$ vs 14$)$ corresponding to the contrast between the five legumes submitted to the mechanical topple and the additional treatment of pre-emergence herbicides and C5 (1 vs 14) corresponding to the contrast between $C$. spectabilis and the additional treatment of herbicide application in pre-emergence.

\section{Results and Discussion}

There was a significant effect of the interaction between soil mulch and management, for dry mass production and weed density at 30 and 60 DAP (Tables 2 and 3). At 30 DAP the suppression efficiency of $C$. spectabilis mulch, has passed from $27 \%$ with topple to $33 \%$ with post + pre herbicides, but there was no difference. Contrast $\mathrm{C} 1$ indicates that there was also no difference in relation to the additional treatment 1 , only with post emergence herbicide. Observed from the above exposed that the common residual effect in pre-emergent herbicides may not be observed at 30 days in weed suppression in sugarcane (Table 2). 
Table 2. Influence of management soil mulch on the production of dry mass and weed density in the area, 30 days after planting sugarcane, Sugarcane Industry Sinimbu, AL

\begin{tabular}{|c|c|c|c|c|c|c|}
\hline \multirow{3}{*}{ Soil Mulch $\left(\mathrm{N}^{\circ}\right)$} & \multicolumn{6}{|c|}{ Weeds 30 days after planting sugarcane } \\
\hline & \multicolumn{3}{|c|}{ Dry Mass $\left(\mathrm{g} \mathrm{m}^{-2}\right)[\%]$} & \multicolumn{3}{|c|}{ Density of plants (plants $\mathrm{m}^{-2}$ ) } \\
\hline & $\begin{array}{l}\text { Mechanical } \\
\text { Manangement }\end{array}$ & $\begin{array}{l}\text { Chemical } \\
\text { Manangement }\end{array}$ & Average & $\begin{array}{l}\text { Mechanical } \\
\text { Manangement }\end{array}$ & $\begin{array}{l}\text { Chemical } \\
\text { Manangement }\end{array}$ & Average \\
\hline C. spectabilis (1 and 2) & $22[27] \mathrm{bA}$ & $20[33] \mathrm{aA}$ & 21 & $32 \mathrm{bA}$ & $14 \mathrm{bA}$ & 23 \\
\hline C. juncea (3 and 4) & $18[40] \mathrm{bA}$ & $15[50] \mathrm{aA}$ & 17 & $211 \mathrm{aA}$ & $11 \mathrm{bB}$ & 111 \\
\hline C. ochroleuca (5 and 6) & $20[33] \mathrm{bA}$ & $11[63] \mathrm{aB}$ & 16 & $58 \mathrm{bA}$ & $6 \mathrm{bB}$ & 32 \\
\hline C. breviflora (7 and 8$)$ & $26[13] \mathrm{aA}$ & $11[63] \mathrm{aB}$ & 19 & $46 \mathrm{bA}$ & $12 \mathrm{bB}$ & 29 \\
\hline Cajanus cajan ( 9 and 10$)$ & $32[0] \mathrm{aA}$ & $15[50] \mathrm{aB}$ & 24 & $46 \mathrm{bA}$ & $32 \mathrm{bA}$ & 39 \\
\hline Without Soil Mulch (11 and 12) & $30[0]$ aA & $10[67] \mathrm{aB}$ & 20 & $53 \mathrm{bA}$ & $71 \mathrm{aA}$ & 62 \\
\hline Average & 25 & 14 & & 74 & 24 & \\
\hline \multicolumn{7}{|l|}{ Additional treatments } \\
\hline C. spectabilis + POST (13) & $28[7]$ & & & 147 & & \\
\hline Without Soil Mulch + PRE (14) & $20[33]$ & & & 146 & & \\
\hline Contrasts $(\mathrm{C})$ & Dry Mass & & & Density of plan & & \\
\hline C1 (1 vs 13) & -1.67 & & & $-7.75 * *$ & & \\
\hline $\mathrm{C} 2(1+3+5+7+9$ vs 11$)$ & $-2.18 *$ & & & $2.22 *$ & & \\
\hline $\mathrm{C} 3(2+4+6+8+10$ vs 12$)$ & 1.50 & & & $-4.83 * *$ & & \\
\hline $\mathrm{C} 4(1+3+5+7+9$ vs 14$)$ & 1.43 & & & $-5.84 * *$ & & \\
\hline C5 (1 vs 14$)$ & 0.66 & & & $-7.65 * *$ & & \\
\hline General Average & 20.09 & & & 63.25 & & \\
\hline $\mathrm{CV} \%$ & 26.41 & & & 33.34 & & \\
\hline
\end{tabular}

Note. Average followed by equal letters, lowercase in the column and uppercase in the line, don't differ by Scott-Knott test up to $5 \%$ probability. ** Significant up to $1 \%$ probability; * significant up to $5 \%$ probability; ns not significant up to $5 \%$ probability; (C) contrasts obtained by the $t$ test, [ ] the brackets bring the percentage efficiency of weed control in relation to the treatment without cover and with mechanical management.

High infestation of one or some weed species is an undesirable condition in which losses occur only for the interest crop. However, the correct management doesn't search the total eradication of weeds, only search to diminish the denser populations (Varella \& Rocha, 1999). In the additional treatment 2, pre-emergence herbicides, the weed density was significantly higher $\left(146\right.$ plants $\left.\mathrm{m}^{-2}\right)$ in relation to the treatment without mulch and without herbicides at 30 DAP. However, the opposite occurred with the dry mass of weeds (Table 2). This shows that plant density shouldn't be analyzed apart from the dry mass of weeds; this could lead to wrong conclusions about the suppressive effect of soil mulch (Oliveira \& Freitas, 2008). 
Table 3. Influence of management soil mulch on the production of dry mass and weed density in the area, 60 days after planting sugarcane, Sugarcane Industry Sinimbu, AL

\begin{tabular}{|c|c|c|c|c|c|c|}
\hline \multirow{3}{*}{ Soil Mulch $\left(\mathrm{N}^{\circ}\right)$} & \multicolumn{6}{|c|}{ Weeds 30 days after planting sugarcane } \\
\hline & \multicolumn{3}{|c|}{ Dry Mass $\left(\mathrm{g} \mathrm{m}^{-2}\right)[\%]$} & \multicolumn{3}{|c|}{ Density of plants (plants $\mathrm{m}^{-2}$ ) } \\
\hline & $\begin{array}{l}\text { Mechanical } \\
\text { Manangement }\end{array}$ & $\begin{array}{l}\text { Chemical } \\
\text { Manangement }\end{array}$ & Average & $\begin{array}{l}\text { Mechanical } \\
\text { Manangement }\end{array}$ & $\begin{array}{l}\text { Chemical } \\
\text { Manangement }\end{array}$ & Average \\
\hline C. spectabilis (1 and 2) & $19[93] \mathrm{cA}$ & $17[93] \mathrm{bA}$ & 18 & $6 \mathrm{cB}$ & $29 \mathrm{dA}$ & 18 \\
\hline C. juncea (3 and 4) & $14[95] \mathrm{cA}$ & $22[92] \mathrm{bA}$ & 18 & $4 \mathrm{cB}$ & $112 \mathrm{aA}$ & 58 \\
\hline C. ochroleuca (5 and 6) & $20[92] \mathrm{cA}$ & $17[93] \mathrm{bA}$ & 19 & $19 \mathrm{bB}$ & $39 \mathrm{cA}$ & 29 \\
\hline C. breviflora (7 and 8) & $120[54] \mathrm{bB}$ & $216[17] \mathrm{aA}$ & 168 & $30 \mathrm{bB}$ & $45 \mathrm{cA}$ & 38 \\
\hline Cajanus cajan (9 and 10$)$ & $13[95] \mathrm{cA}$ & $27[90] \mathrm{bA}$ & 20 & $12 \mathrm{cB}$ & $27 \mathrm{dA}$ & 19 \\
\hline Without Soil Mulch (11 and 12) & $260[0] \mathrm{aA}$ & $18[93] \mathrm{bB}$ & 139 & $144 \mathrm{aA}$ & $76 \mathrm{bB}$ & 110 \\
\hline Average & 74 & 53 & & 36 & 55 & \\
\hline \multicolumn{7}{|l|}{ Additional treatments } \\
\hline C. spectabilis + POST (13) & $16[94]$ & & & 100 & & \\
\hline Without Soil Mulch + PRE (14) & $205[21]$ & & & 121 & & \\
\hline Contrasts $(\mathrm{C})$ & Dry Mass & & & Density of plan & & \\
\hline $\mathrm{C} 1(1$ vs 13$)$ & 0.14 & & & $-13.61 * *$ & & \\
\hline $\mathrm{C} 2(1+3+5+7+9$ vs 11$)$ & $-16.14 * *$ & & & $-24.12^{* *}$ & & \\
\hline $\mathrm{C} 3(2+4+6+8+10$ vs 12$)$ & $3.01 * *$ & & & $-4.79 * *$ & & \\
\hline $\mathrm{C} 4(1+3+5+7+9$ vs 14$)$ & $-12.15^{* *}$ & & & -19.84 & & \\
\hline C5 (1 vs 14$)$ & $-10.44 * *$ & & & $-16.57^{* *}$ & & \\
\hline General Average & 70.48 & & & 54.70 & & \\
\hline $\mathrm{CV} \%$ & 35.73 & & & 17.95 & & \\
\hline
\end{tabular}

Note. Average followed by equal letters, lowercase in the column and uppercase in the line, don't differ by Scott-Knott test up to $5 \%$ probability. ${ }^{* *}$ Significant up to $1 \%$ probability; ${ }^{*}$ significant up to $5 \%$ probability; ns not significant up to $5 \%$ probability; (C) contrasts obtained by the $\mathrm{t}$ test, [ ] the brackets bring the percentage efficiency of weed control in relation to the treatment without cover and with mechanical management.

At 60 DAP of sugarcane cultivation, the soil mulch from C. juncea with mechanical topple overcame by almost 15 times the capacity to control weeds in relation to herbicides in pre-emergence (Table 3). The main effects of soil mulch on weed suppression are cited in Oliveira Neto et al. (2011): the physical barrier causes mechanical resistance to the emergence of weeds, prevents the light that interferes in the germination of positive photoblasts weed seeds, and this management of mulch requires a minimum soil cultivation that contributes to the maintenance the weed seeds dormancy on the soil.

The main weeds occurring in the area belonged to the family Poaceae: Eragrostis ciliares, Eleusine indica and Dactyloctenium aegyptium. However, other species also stood out: Emilia coccinea (Asteraceae) and Mollugo verticillata (Molluginaceae).

The weed density at 60 DAP was significantly higher in treatments that received herbicides compared to soil mulch with mechanical topple (Table 3). Although herbicides provide intense control of weeds, other species of the soil seed bank may be establishing in the crop area (Timossi et al., 2011). There was an interaction effect of the factors studied for culms production per hectare (TCH) and industrial yield (TPH) of sugarcane (Table 4). 
Table 4. Influence of soil mulch on Agricultural Productivity [tons of culm per hectare (TCH)] and Industrial Yield [tons of sugar per hectare (TPH)] of sugarcane, at 12 months of cultivation, Sugarcane Industry Sinimbu, $\mathrm{AL}$

\begin{tabular}{|c|c|c|c|c|c|c|}
\hline \multirow{3}{*}{ Soil Mulch $\left(\mathrm{N}^{\circ}\right)$} & \multicolumn{6}{|c|}{ Agricultural Productivity and Industrial Yield of Sugarcane } \\
\hline & \multicolumn{3}{|c|}{ TCH $\left(\mathrm{t} \mathrm{ha}^{-1}\right)$} & \multicolumn{3}{|c|}{ TPH $\left(\mathrm{t} \mathrm{ha}^{-1}\right)$} \\
\hline & $\begin{array}{l}\text { Mechanical } \\
\text { Manangement }\end{array}$ & $\begin{array}{l}\text { Chemical } \\
\text { Manangement }\end{array}$ & Average & $\begin{array}{l}\text { Mechanical } \\
\text { Manangement }\end{array}$ & $\begin{array}{l}\text { Chemical } \\
\text { Manangement }\end{array}$ & Average \\
\hline C. spectabilis (1 and 2) & $116 \mathrm{aB}$ & $153 \mathrm{aA}$ & 134 & $18 \mathrm{aB}$ & $24 \mathrm{aA}$ & 21 \\
\hline C. juncea (3 and 4$)$ & $92 \mathrm{bB}$ & $136 \mathrm{aA}$ & 114 & $14 \mathrm{bB}$ & $21 \mathrm{bA}$ & 18 \\
\hline C. ochroleuca (5 and 6) & $101 \mathrm{aA}$ & $115 \mathrm{bA}$ & 108 & $15 \mathrm{bB}$ & $18 \mathrm{cA}$ & 16 \\
\hline C. breviflora (7 and 8$)$ & $89 \mathrm{bB}$ & $114 \mathrm{bA}$ & 101 & $13 \mathrm{bB}$ & $17 \mathrm{cA}$ & 15 \\
\hline Cajanus cajan ( 9 and 10$)$ & $107 \mathrm{aA}$ & $111 \mathrm{bA}$ & 109 & $17 \mathrm{aA}$ & $17 \mathrm{cA}$ & 17 \\
\hline Without Soil Mulch (11 and 12) & $84 \mathrm{bB}$ & $135 \mathrm{aA}$ & 109 & $13 \mathrm{bB}$ & $20 \mathrm{bA}$ & 17 \\
\hline Average & 98 & 128 & & 15 & 20 & \\
\hline \multicolumn{7}{|l|}{ Additional treatments } \\
\hline C. spectabilis + POS (13) & 116 & & & 18 & & \\
\hline Without Soil Mulch + PRE (14) & 97 & & & 15 & & \\
\hline Contrasts & $\mathrm{TCH}$ & & & $\mathrm{TPH}$ & & \\
\hline C1 (1 vs 13) & 0.09 & & & 0.39 & & \\
\hline $\mathrm{C} 2(1+3+5+7+9$ vs 11$)$ & $2.57 *$ & & & $2.69^{*}$ & & \\
\hline $\mathrm{C} 3(2+4+6+8+10$ vs 12$)$ & -1.37 & & & -0.98 & & \\
\hline $\mathrm{C} 4(1+3+5+7+9$ vs 14$)$ & 0.60 & & & 0.74 & & \\
\hline C5 (1 vs 14$)$ & $2.29 *$ & & & $2.51 *$ & & \\
\hline General Average & 112.06 & & & 17.22 & & \\
\hline $\mathrm{CV} \%$ & 10.75 & & & 11.28 & & \\
\hline
\end{tabular}

Note. Average followed by equal letters, lowercase in the column and uppercase in the line, don't differ by Scott-Knott test up to $5 \%$ probability. ** Significant up to $1 \%$ probability; * significant up to $5 \%$ probability; ns not significant up to $5 \%$ probability; (C) contrasts obtained by the t-test.

The agricultural productivity (TCH) was significantly higher for treatments with soil mulch from C. spectabilis, C. ochroleuca and Cajanus cajan with mechanical topple, in relation to the uncovered area, in the option of mechanical management. This productivity increase isn't only related to the efficiency of suppressing weeds of the soil mulch, since the coverage of $C$. juncea with topple had the same suppression efficiency at 60 DAP as the mulch's cited (Table 3). However, it hasn't now presented the same agricultural productivity. Another research verified that the root system of the legumes: $C$. spectabilis, C. ochroleuca and Cajanus cajan, are very extensive and deep, in the formation of the soil mulch the decomposed roots of the legumes serve as biopores in the soil, that allow greater infiltration and availability of water for sugarcane cultivated in the same area, which would justify the increase of agricultural productivity (Cerqueira, 2011) (Table 4).

The use of herbicides in the formation of mulch seemed to contribute to a faster mineralization in the stage of decomposition of mulch in Crotalaria spectabilis, for example, this would justify the increase of productivity with the use of herbicides (Tables 3 and 4), because the suppression of weeds presented the same efficiency for the two treatments. Boer et al. (2008) also observed that when the soil cover was managed with chemical desiccation, an increase in the decomposition velocity of the vegetal remains occurred, causing a greater availability of nutrients to the soil, which would favor the production of the sugarcane under the herbicide management.

The absence of weed control until the 60 days of sugarcane cultivation, in the treatment without soil mulch and without herbicides, reduced the sugar production per hectare by $35 \%$, in relation to the control with herbicides (pre and post), also reduced by $45 \%$ compared to treatment of soil mulch from $C$. spectabilis with herbicides. The treatments without soil mulch and without herbicides presented agricultural losses and losses of industrial yield around 35\% (Table 4).

\section{Conclusion}

The soil mulch from C. spectabilis, C. juncea, C. ochroleuca, C. breviflora and Cajanus cajan was less efficient in suppressing weeds than the treatment with herbicides applied in pre-emergence + post-emergence. 
On the other hand, they were more efficient in the control of weeds in relation to the use of herbicides in pre-emergence, fact observed at 60 days of sugarcane cultivation.

Soil mulch from C. spectabilis showed the same weed control efficiency and the same effect on sugarcane (first harvest/cut) productivity, both with mechanical management and with additional management with post-emergence herbicides.

\section{References}

Boer, C. A., Assis, L. R., Silva, G. P., Braz, A. J. B. P., Barroso, A. L. L., Cargnelutti Filho, A., \& Pires, F. R. (2008). Biomassa, decomposição e cobertura do solo ocasionada por resíduos culturais de três espécies vegetais na região Centro-Oeste do Brasil. Revista Brasileira de Ciência do Solo, 32(2), 843-851. https://doi.org/10.1590/S0100-06832008000200038

Braun-Blanquet, J. (1950). Sociología vegetal: Estudios de las comunidades vegetales. Buenos Aires, Acme Agency.

Cerqueira, D. C. O. (2011). Caracterização de leguminosas para adubação verde de canaviais em solo de Tabuleiro Costeiro, Penedo, Alagoas (Dissertation, Federal University of Alagoas).

Embrapa (Empresa Brasileira De Pesquisa Agropecuária). (2013). Sistema brasileiro de classificação dos solos (3rd ed.). Rio de Janeiro: CNPS.

Garcia-Franco, N., Albaladejo, J., Almagro, M., \& Martínez-Mena, M. (2015). Beneficial effects of reduced tillage and green manure on soil aggregation and stabilization of organic carbon in a Mediterranean agroecosystem. Soil and Tillage Research, 153, 66-75. https://doi.org/10.1016/j.still.2015.05.010

Gomes, D. S., Bevilaqua, N. C., Silva, F. B., \& Monquero, P. A. (2014). Supressão de plantas espontâneas pelo uso de cobertura vegetal de crotalária e sorgo. Revista Brasileira de Agroecologia, 9(2), 206-213.

Guimarães, S. C., Souza, I. F., \& Pinho, E. V. R. V. (2002). Emergência de Tridax procumbens em função da profundidade de semeadura, do conteúdo de argila no substrato e da incidência de luz na semente. Planta Daninha, 20(3), 413-419. https://doi.org/10.1590/S0100-83582002000300012

Mhlanga, B., Cheesman, S., Maasdorp, B., Muoni, T., Mabasa, S., Mangosho, E., \& Thierfelder, C. (2015). Weed community responses to rotations with cover crops in maize-based conservation agriculture systems of Zimbabwe. Crop Protection, 69, 1-8. https://doi.org/10.1016/j.cropro.2014.11.010

Monquero, P. A., Amaral, L. R., Inácio, E. M., Brunhara, J. P., Binha, D. P., Silva, P. V., \& Silva, A. C. (2009). Efeito de adubos verdes na supressão de espécies de plantas daninhas. Planta Daninha, 27(1), 85-95. https://doi.org/10.1590/S0100-83582009000100012

Mueller, T. C., \& Senseman, S. A. (2015). Methods related to herbicide dissipation or degradation under field or laboratory conditions. Weed Science, 63(1), 133-139. https://doi.org/10.1614/WS-D-13-00157.1

Oliveira Neto, A. M., Goes, M. C. D., Guerra, N., Lima, G. G. R., \& Júnior, L. C. S. (2011). Manejo químico de adubos verdes para sucessão da cana-de-açúcar em sistema de cultivo mínimo. Revista Brasileira de Herbicidas, 10(2), 86-94. https://doi.org/10.7824/rbh.v10i2.110

Oliveira, A. R., \& Freitas, S. P. (2008). Levantamento fitossociológico de plantas daninhas em áreas de produção de cana-de-açúcar. Planta Daninha, 26(1), 33-46. https://doi.org/10.1590/S0100-83582008000100004.

Oliveira, M. W., Silva, V. S. G., Calheiros, A. S., Oliveira, T. B. A., Nogueira, C. H. C., Paula, A. C. B., \& Oliveira, Y. M. (2017). Growth and nutrient accumulation of Crotalaria juncea sown in october or November. Asian Academic Research Journal of Multidisciplinar, 4(10), 57-67.

Samsel, A., \& Seneff, S. (2013). Glyphosate, pathways to modern diseases II: Celiac sprue and gluten intolerance. Interdisciplinary Toxicology, 6(4), 159-184. https://doi.org/10.2478/intox-2013-0026

Santos, C. E. R. S., Silva, V. S. G., Freitas, A. D. S., Silva, A. F., Bezerra, R. V., \& Ferreira, J. S. (2017). Prospecting of efficient rhizobia for peanut inoculation in a Planosol under different vegetation covers. African Journal of Microbiology Research, 11(4), 123-131. https://doi.org/10.5897/AJMR2016.8355

Sharifi, M., Lynch, D. H., Hammermeister, A., Burton, D. L., \& Messiga, A. J. (2014). Effect of green manure and supplemental fertility amendments on selected soil quality parameters in an organic potato rotation in Eastern Canada. Nutrient Cycling in Agroecosystems, 100(2), 135-146. https://doi.org/10.1007/s10705-014-9633-x 
Silva, F. A. S., \& Azevedo, C. A. V. (2016). The Assistat software version 7.7 and its use in the analysis of experimental data. African Journal of Agricultural Research, 11(39), 3733-3740. https://doi.org/10.5897/ AJAR2016.11522

Silva, P. D. A., Marafon, A., Ivo, W. D. M., Paiva, H., Guimaraes, V. D. S., \& Neves, J. A. (2016b). Uso de leguminosas na renovação de canaviais: Espécies recomendadas para diferentes épocas de plantio nos tabuleiros costeiros de Alagoas. Comunicado Técnico, 196. Aracaju: Embrapa Tabuleiros Costeiros.

Teixeira, R. A., Soares, T. G., Fernandes, A. R., \& Braz, A. M. D. S. (2014). Grasses and legumes as covers crop in no-tillage system in northeastern Pará Brazil. Acta Amazonica, 44(4), 411-418. https://doi.org/10.1590/ $1809-4392201305364$

Timossi, P. C., Wisintainer, C., Santos, B. J. D., Pereira, V. A., \& Porto, V. S. (2011). Supressão de plantas daninhas e produção de sementes de crotálaria, em função de métodos de semeadura. Pesquisa Agropecuária Tropical, 41(4), 525-530. https://doi.org/10.5216/pat.v41i4.11603

Varella, M. D., \& Rocha, F. A. G. (1999). Biossegurança e biodiversidade: Contexto científico e regulamentar. Del Rey.

Yamauti, M. S., Barroso, A. A. M., Giancotti, P. R. F., Squasoni, V. L., Revolti, L. T. M., \& Alves, P. L. C. A. (2011). Emergência de plantas daninhas em função da posição da semente e quantidade de palha de cana-de-açúcar. Scientia Agraria, 12(2), 75-80.

\section{Copyrights}

Copyright for this article is retained by the author (s), with first publication rights granted to the journal.

This is an open-access article distributed under the terms and conditions of the Creative Commons Attribution license (http://creativecommons.org/licenses/by/4.0/). 